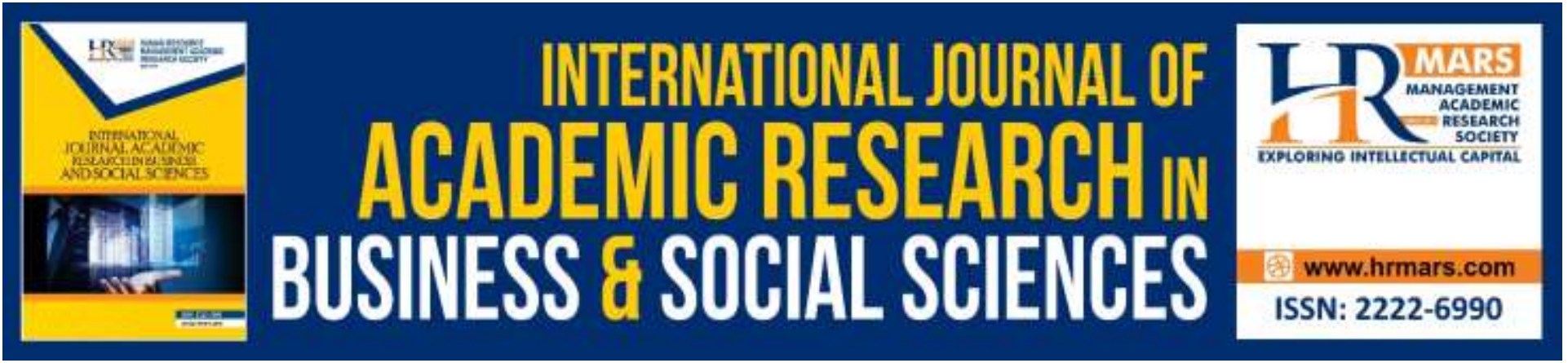

\title{
The Effect of Mobile Gallery Walk towards Students' Interest and Performance in Economic
}

\section{Mazdalifa Makmun, Khoo Yin Yin and Zainizam Zakariya}

To Link this Article: http://dx.doi.org/10.6007/IJARBSS/v9-i7/6682

DOI: 10.6007/IJARBSS/v9-i7/6682

Received: 02 May 2019, Revised: 17 June 2019, Accepted: 30 June 2019

Published Online: 03 July 2019

In-Text Citation: (Makmun, Yin, and Zakariya, 2019)

To Cite this Article: Makmun, M., Yin, K. Y., and Zakariya, Z. (2019).The Effect of Mobile Gallery Walk towards Students' Interest and Performance in Economic. International Journal of Academic Research in Business and Social Sciences, 9(7), 1378-1390.

\section{Copyright: (C) 2019 The Author(s)}

Published by Human Resource Management Academic Research Society (www.hrmars.com)

This article is published under the Creative Commons Attribution (CC BY 4.0) license. Anyone may reproduce, distribute, translate and create derivative works of this article (for both commercial and non-commercial purposes), subject to full attribution to the original publication and authors. The full terms of this license may be seen

at: http://creativecommons.org/licences/by/4.0/legalcode

Vol. 9, No. 7, 2019, Pg. 1378 - 1390

http://hrmars.com/index.php/pages/detail/IJARBSS

JOURNAL HOMEPAGE

Full Terms \& Conditions of access and use can be found at http://hrmars.com/index.php/pages/detail/publication-ethics 


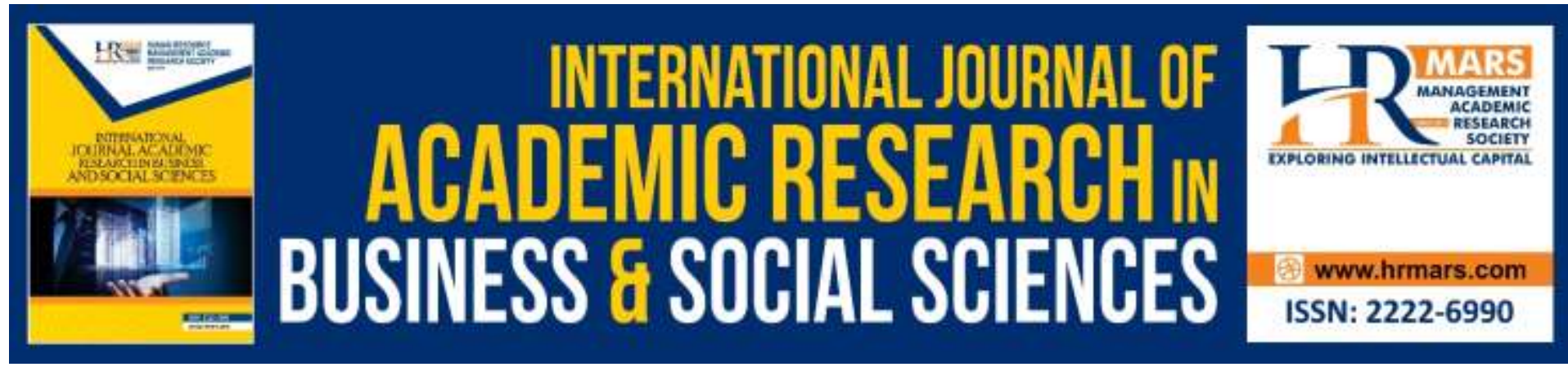

\title{
The Effect of Mobile Gallery Walk towards Students' Interest and Performance in Economic
}

\author{
Mazdalifa Makmun, Khoo Yin Yin and Zainizam Zakariya \\ Department of Economics, Faculty of Management and Economics, Sultan Idris Education \\ University, Perak, Malaysia
}

\begin{abstract}
The purpose of this study is to examine the effect of mobile gallery walk (MGW) towards students' interest and performance in Economic. Quantitative designs of quasi experiments were selected based on pre-test and post-test techniques. Sample size of 99 secondary students was selected and divided into three groups, which are two experimental group (KMGW and KGW) and one control group (KK). Experimental groups consisted of 30 (KMGW) and 35 (KGW) respondents while the control group consisted of 34 (KK) respondents. The simple random sampling was used as a sampling technique used in this study. Data was gathered using exam question and survey questioner. The data was analysed using descriptive and inferential statistical technique. The impact of KMGW, KGW and KK on student interest and performance was analysed using MANCOVA while the relationship between interest and student performance was measured using the Pearson correlation. The results showed that there was a significant difference in the interest and performance of students using KMGW compared with the group of students exposed to KGW and KK. This indirectly shows that KMGW is effective in increasing the interest and performance of students taking economic subjects compared to groups of students exposed to KGW and KK. The findings also showed that there was a strong positive relationship was found between interest and performance of students exposed to KMGW. Overall, mobile gallery walk method is very effective for students in Economics because they can increase their interest and performance to learn compared to gallery walk method and conventional methods. These finding can help school administrators, to encourage teachers to use new technology in teaching and learning process. Finding from this study can be used to carry out future research and to improve the current education system.
\end{abstract}

Keywords: Mobile Gallery Walk, Interest, Performance

\section{Introduction}

According to the rapid development of today's technology world, the transformation and evolution of the national education system needs to be improve to produce positive impact on student learning (Simelane \& Mji, 2014). Ministry of Education considers that by using ICT in learning can revolutionize the learning process, strengthen the development of pedagogy 
and boost student mastery (Ministry of Education, 2013). According to Rodenbaugh (2015) and Kennedy, Mimmack and Flannery (2012), gallery walk is a learning tool that allows students to move, think and talk to each other. Meanwhile, the Kruea-In and Thongperm (2014) also showed that gallery walk can enhance time management, student engagement and student accountability as well as group discussions can be enhanced (Rodenbaugh, 2015; Kruea-In and Thongperm, 2014). In addition, the results of the study by Teodoro, Donders, Davidson, Robertson \& Schuyler (2011) also introduced new information to create and motivated students to engage in learning activities and stimulate them to move further to the station - other stations and move actively in the gallery walk activities. Researchers also used mobile technology into gallery walk activities using Padlet and HR Reveal applications as a mobile technology to see the effect of using mobile gallery walk learning methods on students' interest and achievement in Economics.

\section{Problem Statement}

There are some problems that have been identified in this study. Students who take the Basic Economics subjects need to master the three key aspects of theory, analysis and application in order to achieve excellent performance (Normala et al., 2014). This situation poses a huge challenge to teachers to increase students' understanding of Economic theory and analysis. The performance problems of students across Malaysia have been declined in the early stages of Economics subjects introduced in 1992 (Normala et al., 2014). This weakness is due to weakness in academic performance of students, negative perceptions of students on economics subjects and inadequate teaching time (Normala et al., 2014). This situation is a great challenge for teachers to educate students and teachers should use ICT as the primary medium to achieve the maximum level of learning success.

Based on the results of the SPM examination, there was an increase in the percentage of approval for the Basic Economics subject in 2016 to 2017 from 6.39 to 6.29. However the Average Grade Score (GPMP) from 2016 to 2017 for Basic Economics subjects is more than 5.00 (Ministry of Education, 2017). This situation showed that the quality of the students' performance is not satisfactory. This proves that there is a problem in mastering Basic Economics subjects and the best approach should be done by teachers by applying ICT in school learning.

Table 1.

The Average Grade Score (GPMP) from 2016 to 2017 for Basic Economics subjects.

\begin{tabular}{|c|c|c|c|c|c|c|c|c|}
\hline \multirow[b]{2}{*}{ Subject } & \multirow[b]{2}{*}{ Year } & \multicolumn{5}{|c|}{ Percentage of students } & \multirow[b]{2}{*}{$\mathrm{N}$} & \multirow[b]{2}{*}{ GPMP } \\
\hline & & $A+, A, A-$ & $\mathrm{B}+, \mathrm{B}, \mathrm{C}+, \mathrm{C}$ & $D, E$ & $A+\rightarrow e$ & $\begin{array}{c}\text { Fail } \\
\text { G }\end{array}$ & & \\
\hline \multirow{3}{*}{$\begin{array}{l}\text { Basic } \\
\text { Economic }\end{array}$} & 2017 & 9.1 & 30.8 & 43.9 & 83.8 & 16.2 & 61,321 & 6.29 \\
\hline & 2016 & 9.9 & 28.8 & 41.5 & 80.2 & 19.8 & 63,624 & 6.39 \\
\hline & Different & -0.8 & 2.0 & 2.4 & 3.6 & -3.6 & -2.303 & -0.10 \\
\hline
\end{tabular}




\section{Research Questions}

1. Are there changes in students' interest for the period before and after the implementation of mobile gallery walk (KMGW) compared to Gallery Walk (KGW) and the conventional method (KK) of learning method in the Economics subject?

2. Are there changes in student's performance for the period before and after the implementation of mobile gallery walk (KMGW) compared to Gallery Walk (KGW) and the conventional method (KK) of learning method in the Economics subject?

\section{Research Hypotheses}

$\mathrm{H}_{01}$ : There was no significant difference between the effect of using Mobile Gallery Walk (KMGW) method compared to the use of Gallery Walk Method (KGW) and Conventional Methods (KK) on student interest.

$\mathrm{H}_{02}$ : There was no significant difference between the effect of using Mobile Gallery Walk (KMGW) method compared to the use of Gallery Walk Method (KGW) and Conventional Methods (KK) on student performance.

$\mathrm{H}_{03}$ : There is no significant relationship between the interest and performance of students taking economic subjects through the mobile gallery walk (KMGW) Method.

\section{Literature Review \\ Gallery Walk}

Gallery Walk has many benefits to the teaching and learning process as the gallery walk stimulates critical thinking, communication and can apply critical evaluation to new information (Rodenbaugh, 2015). In addition, the use of gallery walk method in teaching and learning process can increase students' interest (Rodenbaugh, 2015; Hendri et al., 2017; Maulida et al., 2017). While according to Kahayun et al., (2015) the gallery walk method has a positive impact on the student's interest.

The used of gallery walk as learning method can improves student performance (Farrah, 2015). The statements also supported by Hendri et al. (2017) gallery walk method has a positive effect on student's performance. The studies above can prove that the teaching and learning method of mobile walk gallery can increase the interest and performance of the students. Therefore desirable for researchers to use the walk-in gallery method to see the impact of their use on the interests and performance of Economics students. Researchers also insert mobile technology into gallery walk activities using the Padlet and HP Reveal app as a mobile technology to see the effect of using a mobile gallery learning method on the interests and achievement of Economics students.

\section{Mobile learning}

The presence of the internet and the extensive use of computers has created new terms for distance learning known as mobile learning (Maslin et al., 2016). According to Noorhadi and Zurinah (2017), m-learning method has a positive effect on student's interest. In addition, the used of m-learning methods in learning processes can increase student interest (Chen et al., 2013; Hashim et al., 2014; Adeyemo et al., 2013; Halim et al., 2016; Noorhadi \& Zurinah, 2017). The used of m-learning method in learning process can improve student's performance (Macaluso \& Hughes, 2015; Yang \& Wu, 2012). Whereas according to Shih, Chuang and Hwang (2010) and Darrell (2013) m-learning method has positive effect on student's performance. 
Hence, can be concluded that mobile learning can affect the student's interest. It will indirectly improve student performance. It is therefore desirable for researchers to use the mobile gallery walk method to see the impact of their use on the interest of Economics students.

\section{Relationship between Interest and Performance}

Strang, (2016) in his study says that what the educators need to emulate is that fertilizing interests should be done from the beginning of the level so that their achievements can be formed from the beginning. Results of the study conducted by Erma (2014); Sabriyadi et al. (2015) shows that students' attitudes, interests and strategies of teaching the subject have positive relationships with student achievement. Teodoro, Donders, Davidson, Robertson \& Schuyler (2011) found that these attitudes and interests factor can affect the goals and ambitions of a student with a score of $98.5 \%$ of respondents agree. Students studying with high interest will be delighted and encouraged to work harder in achieving goals, which is to obtain grade A in examination (Teodoro et al. 2011). In order to increase the achievement and increase the interest and motivation of students, a student centred teaching approach is practiced to create a more positive attitude among students (Zakariya \& Bamidele, 2015). Hence, it can be concluded that the interest factor can affect the student's performance.

\section{Methodology \\ Research Design}

This study uses a quantitative approach that implements quasi experimental designs. This study uses experimental designs by conducting quasi-experimental procedures and techniques that use questionnaire and performance testing techniques for control groups and experimental groups. The sample of the students involved in the study consisted of three groups, consisting of two experimental groups and one control group. Samples of students involved in each experimental group each were given exposure on the mobile gallery walk (KMGW) method and gallery walk method (KGW). Nevertheless, the sample of students who belong to the control group only uses the existing method of learning methods in the form of conventional methods (KK). The implementation of the test in this study involved two instruments, namely questionnaire instrument and performance test instrument. All of the sample students who belong to the three study groups are asked to answer the questionnaire and undergo a performance test as a test and post-test. However, only a sample of students who belong to the experimental group only undergo treatment sessions and receive intervention for eight weeks. In relation to the study conducted, the treatment given in the intervention session to the experimental group is exposure to the technology assisted learning method known as the mobile gallery method (KMGW) and exposure to the gallery walk method known as the gallery walk method (KGW). At the end of the experiment, the researchers analysed the effect of the KMGW and KGW methods on students' interest and performance based on the results obtained in the pre-test and post-test.

\section{Population and Sample}

The population of study was 320 students being choosed in one of school located in Zon Sepang, Selangor in Malaysia. The sample size was 110 students from population based on Cohen (1988). Respondents were randomly selected among the students of Economic in Zon 
Sepang, Selangor. The study was conducted by quantitative methods using questionnaires and performance test.

\section{Sampling Method Instrument}

There are two instruments in this study which is a performance test to obtain student performance scores and questionnaires to obtain a mean score of student interest. This study involved two set of questionnaire and performance test that was provided by the researcher before the study was conducted. A set of questionnaires and performance tests were required to be answered by the sample during the test period after the researchers distributed the questionnaires to all study samples, while a set of questionnaires and performance tests were again answered by the student sample after the experiment was completed. This research instrument is prepared for evaluation purposes in pre-trial and postgraduate studies for economics subjects as their elective subject.

The questionnaire used in this study was adapted from the questionnaires prepared by Khoo, Al-Huda, Hafsah, Norasibah, and Radziah (2015) and Shaharuddin et al. (2014). The questionnaire used in the pre-test and post-test consists of 35 items covering Part $A$ and Part B. Part A is related to the student's demography consisting of 5 items of questions, while part $B$ is concerned with the student's interest in the use of the learning method used consists of 30 questions using 5 point Likert scale for each answer option. Student performance tests are modified from training questions issued by Phang (2018) and SPM exam questions from 2015 to 2017. The performance tests used in this test contain 40 questions. Field experts had been selected to confirm for performance tests that had been modified by researchers.

\section{Pilot Study}

In this study, this pilot study has been conducted on 35 sample students who follow the car gallery walk method (KMGW) at one of the other schools compared to where the actual survey is conducted. However, only 30 samples of the study were answered in complete questionnaire. Therefore, completed questionnaires are only used for analysis to obtain the reliability of the instrument. All student samples belonging to this pilot study were excluded from the sample used for the actual study. The result of this study found that the value of Cronbach's Alpha obtained was 0.977 . The results of pilot tests found that the overall value of Cronbach's Alpha for research instruments was high. So the instrument of this study is very suitable to be used as a research instrument in the actual study. Therefore, overall reliability in pilot studies is good.

\section{Research Procedure}

In the early stages, researchers will ask permission from the school to conduct a study at the school. After getting permission, researcher give explanation to teachers and students according how to implement mobile gallery walk and gallery walk method during learning process. Information given related to this study aims to improve the understanding of teachers and students in this study. In the pre-test to post-test, the researchers will provide the necessary assistance to the school to carry out this research efficiently and effectively. Therefore, a briefing on the pre-test and post-test was given to teachers and students. 
After the researcher gave an explanation to the teachers and students, a pilot study was conducted to determine the validity and reliability of the questionnaire. To run the pretest, the researchers gave questionnaires and performance tests to all groups and were given time to respond to both instruments. After the pre-test was completed, the researchers collected questionnaires and answers papers from the respondents. Post-test will be performed on all groups after eight weeks of street methods used mobile gallery. Finally, data were collected for analysis.

\section{Data Collection and Data Analysis}

The questionnaire was given to 99 students in the selected high school. Data were analyzed using descriptive and inferential statistics. The data is recorded and analyzed into a statistical package for social science (SPSS). Data is filtered and tested for normality. Evaluating normality is necessary as this study uses parametric statistical techniques. Normality is assessed by gaining the value of skewness and kurtosis and the value obtained is within the range of normal distribution.

\section{Results}

A total of 99 students have answered questionnaire and performance test instruments. The analysis results are shown in the following table.

\section{Research Question One}

Are there changes in students' interest for the period before and after the implementation of mobile gallery walk (KMGW) compared to Gallery Walk (KGW) and the conventional method (KK) of learning method in the Economics subject?

Based on the table 2 result showed that the KMGW group obtained mean scores (mean $=2.0300), \mathrm{sd}=.08367$ ) compared to mean score of students interest in KGW group ( mean $=2.0162$, sd $=.07065)$ and KK group (mean $=2.0127, \mathrm{sd}=.07522)$ before treatment given to the experimental group. Meanwhile, after the treatment was given to the experimental group, it was found that the mean value of students' interest in KMGW (min = $4.4805, \mathrm{SD}=.09552$ ) was higher than the students' interest score in KGW group (mean = 3.7043 ) and KK group ( $\min =2.0392, S D=.25299)$. Thus, this situation showed that there is a change in interest rate scores for the group of students exposed to KMGW, KGW and KK for pre and post-treatment periods given to the experimental group (KMGW and KGW) and control group (KK). 
Table 2.

Summary Comparison of Mean and Standard Deviation (SD) on the duration of the pre and post-tests of Dependent Variable (Interest)

\begin{tabular}{|c|c|c|c|c|c|c|}
\hline \multirow{3}{*}{$\begin{array}{l}\text { Learning } \\
\text { method }\end{array}$} & \multicolumn{6}{|c|}{ Interest } \\
\hline & \multicolumn{2}{|c|}{$\begin{array}{c}\text { KMGW } \\
\text { (experimental } \\
\text { group) }\end{array}$} & \multicolumn{2}{|c|}{$\begin{array}{c}\text { KGW } \\
\text { (experimental } \\
\text { group) }\end{array}$} & \multicolumn{2}{|c|}{$\begin{array}{c}\text { KK } \\
\text { (control group) }\end{array}$} \\
\hline & $\begin{array}{l}\text { Pre } \\
\text { test }\end{array}$ & $\begin{array}{l}\text { Post } \\
\text { test }\end{array}$ & Pre test & Post test & Pre test & Post test \\
\hline Mean & 2.0300 & 4.4805 & 2.0162 & 3.7043 & 2.0127 & 2.0392 \\
\hline SD & .08367 & .09552 & .07065 & .49130 & .07522 & .25299 \\
\hline $\mathrm{N}$ & 30 & 30 & 35 & 35 & 34 & 34 \\
\hline
\end{tabular}

\section{Research Question Two}

Are there changes in student's performance for the period before and after the implementation of mobile gallery walk (KMGW) compared to Gallery Walk (KGW) and the conventional method (KK) of learning method in the Economics subject?

Based on table 3 result showed that the KMGW group obtained a mean score of performance $($ mean $=57.27, \mathrm{SD}=7.552$ ) compared to mean score of KGW group (mean 59.40, $\mathrm{SD}=7.163$ ) and KK group (mean=52.76, SD=6.344) before treatment given to the experimental group. Meanwhile, after the treatment was given to the experimental group, it was found that the mean value KMGW group (mean $=80.30, \mathrm{SD}=8.417$ ) was higher than student with KGW group (mean $=72.43, S D=5.658$ ) and KK group (mean $=56.91, S D=6.082$ ). Thus, the situation showed that there is a change in the mean score for the group of students exposed to KMGW, KGW and KK for pre and post-treatment periods given to the experimental group (KMGW and KGW) and control group (KK).

Table 3.

Summary Comparison of Mean and Standard Deviation (SP) on the duration of the pre and post-tests of Dependent Variable (performance)

\begin{tabular}{|c|c|c|c|c|c|c|}
\hline \multirow{3}{*}{ Learning method } & \multicolumn{6}{|c|}{ Performance } \\
\hline & \multicolumn{2}{|c|}{$\begin{array}{c}\text { KMGW } \\
\text { (experimental } \\
\text { group) }\end{array}$} & \multicolumn{2}{|c|}{$\begin{array}{c}\text { KGW } \\
\text { (experimental } \\
\text { group) }\end{array}$} & \multicolumn{2}{|c|}{$\begin{array}{c}\text { KK } \\
\text { (control group) }\end{array}$} \\
\hline & Pre test & Post test & Pre test & Post test & Pre test & $\begin{array}{l}\text { Post } \\
\text { test }\end{array}$ \\
\hline Min & 57.27 & 80.30 & 59.40 & 72.43 & 52.76 & 56.91 \\
\hline SD & 7.552 & 8.417 & 7.163 & 5.658 & 6.344 & 6.082 \\
\hline$N$ & 30 & 30 & 35 & 35 & 34 & 34 \\
\hline
\end{tabular}




\section{Hypothesis 1 and 2}

$\mathrm{H}_{01}$ : There was no significant difference between the effect of using Mobile Gallery Walk (KMGW) method compared to the use of Gallery Walk Method (KGW) and Conventional Methods (KK) on student interest.

$\mathrm{H}_{02}$ : There was no significant difference between the effect of using Mobile Gallery Walk (KMGW) method compared to the use of Gallery Walk Method (KGW) and Conventional Methods (KK) on student performance.

Table 4 showed a summary of multivariate analysis of covariance (MANCOVA) results by student learning method and follow-up of analysis of covariance (ANCOVA) on three groups of learning methods. The result of the analysis showed that the Pillai's Trace Multivariate test showed that there was an independent variable effect of significant learning method $(F=$ $49.989, \mathrm{p}<.05$ ) on the study. This implies that the learning method has a major effect on at least one dependent variable. Not only that, the control variable (covariate) which is a performance pre-test $(F=17.459, p<.05)$ also has a significant effect on student's interest and performance. This situation showed that there are some significant differences between group of students exposed to KMGW, KGW and KK on at least one dependent variable. Hence, the results of the analysis show that KMGW has a significantly differentiate compared to the KGW and KK learning methods on at least one dependent variable.

Table 4.

Summary of Multivariate Analysis of Covariance (MANCOVA) Results by Student Learning Method and Follow-up Analysis of Covariance (ANCOVA) on Three Learning Method Groups

\begin{tabular}{lcc}
\hline $\begin{array}{l}\text { MANCOVA effect, } \\
\text { dependent variables and } \\
\text { covariate }\end{array}$ & $\begin{array}{c}\text { Multivariate F Pillai's } \\
\text { Trace }\end{array}$ & Univariate F df=3,95 \\
\hline $\begin{array}{l}\text { Group effect } \\
\text { Interest }\end{array}$ & $49.989(p=.000)$ & $316.559(p=.000)$ \\
$\begin{array}{l}\text { Performance } \\
\text { Pre performance }\end{array}$ & $93.938 \quad(p=.000)$ \\
\hline
\end{tabular}

The table shows the comparative effects between the three groups of learning methods that are groups exposed with KMGW, KGW and KK. The findings show that there are significant effects on learning methods on interest variables $(F=316.559, p<.50)$. In short, $\mathrm{H}_{01}$ stated that there was no significant difference between the effect of KMGW method compared to the use of KGW and KK was successfully rejected. Thus, there was a significant difference between the effect of the use of the mobile gallery walk (KMGW) method compared to the use of gallery walk method (KGW) and the conventional method (KK)

Similarly, the comparative analysis of the effects between the three groups of learning methods is the group that is exposed with KMGW, KGW and KK. The results also showed that there were significant effects on learning methods on performance variables ( $F=93.938, p$ $<.05)$. Thus, $\mathrm{H}_{02}$ stated that there was no significant difference between the effect of using KMGW method compared to the use of the KGW and KK method was successfully rejected. This situation shows that the method of learning that is exposed to Economics students 
affects students' performance. In summary, the results show that there is a significant difference between the effect of using mobile gallery walk(KMGW) method compared to the use of gallery walk method (KGW) and conventional method (KK) on the interest and performance of Economics students.

Table 5.

The result of ANCOVA Test for Pre-test Performance between Control Group and Experimental Group ( $N=99)$

\begin{tabular}{llll}
\hline Source & Type III Sum of Squares & $F$ & Sig. \\
\hline Interest & Group comparison & 316.559 & .000 \\
& (MGW, GW, CC) & & \\
& Error & $\mathrm{df}=3,95$ & \\
Performance & Group comparison & 93.938 & .000 \\
& (MGW, GW, CC) & & \\
& Error & $\mathrm{df}=3,95$ & \\
& & & \\
& &
\end{tabular}

R Squared $=.877$ (Adjusted R Squared $=.873$ )

$\mathrm{R}$ Squared $=.743$ (Adjusted R Squared $=.735$ )

\section{Hypothesis 3}

$\mathrm{H}_{03}$ : There is no significant relationship between the interest and performance of students taking economic subjects through the mobile gallery walk (KMGW) method.

The correlation coefficient $(r)$ between interest and achievement is worth .766. This shows that there is a strong positive relationship between interest and performance. Given that the probability value obtained $(.000<.05)$ is less than the specified alpha value $(.05)$, then the hypothesis states that there is no significant relationship between the interest and performance of students taking economic subjects through the mobile gallery walk method KMGW) was successfully rejected. The findings of this study implies that Economics students who have high interest in the mobile gallery walk (KMGW) also have a tendency to have high performance levels. Thus, the tendency of performance for students taking Economics subjects can be expected based on the level of students' interest in learning methods that have been exposed to them.

Table 6.

The Correlation between interest and students' performance through mobile gallery walk

\begin{tabular}{llll}
\hline & & Interest & Performance \\
\hline Interest & Pearson Correlation & 1 & $.766^{* *}$ \\
& Sig. (2-tailed) & & .000 \\
Performance & $\mathrm{N}$ & 99 & 99 \\
& Pearson Correlation & $.766^{* *}$ & 1 \\
& Sig. (2-tailed) & .000 & \\
& $\mathrm{~N}$ & 99 & 99 \\
\hline
\end{tabular}


**Correlation is significant at the 0.01 level (2-tailed)

\section{Discussion}

Hypothesis $1\left(\mathrm{H}_{01}\right)$ had been rejected. There was significant difference between the effect of using Mobile Gallery Walk (KMGW) method compared to the use of Gallery Walk Method (KGW) and Conventional Methods (KK) on student interest. The findings of the study Mariyaningsih (2014) has the similarity who said KMGW contributes to students' interest. Meanwhile, the findings Mark (2006) also showed that KMGW has a significant impact on the interest. In addition, the results of the study by Rodenbaugh (2015) also showed that gallery walk contributed significantly to students' interest.

Hypothesis $2\left(\mathrm{H}_{02}\right)$ also was successfully rejected by showed that there was significant difference between the effect of using Mobile Gallery Walk (KMGW) method compared to the use of Gallery Walk Method (KGW) and Conventional Methods (KK) on student performance. The findings of the study Fannia, Rini \& Arman (2017) has the similarity who said KMGW contributes to students' performance. Meanwhile, the findings Franzblau \& Haque (2018) also showed that KMGW has a significant impact on the performance. In addition, the results of the study by Kennedy, Mimmack \& Flannery (2012) also showed that gallery walk contributed significantly to students' performance.

Hypothesis $3\left(\mathrm{H}_{03}\right)$ was successfully rejected. There is significant relationship between the interest and performance of students taking economic subjects through the mobile gallery walk (KMGW) method. The findings of the study Erma (2014) has the similarity who said interest has positive relationship to students' performance. Meanwhile, the findings Sabriyadi, Nana and Tatang (2015) also showed that students' interest has a significant relationship on the performance. In addition, the results of the study by Rosnidar, Haeidatul, Norazilawati and Azmah (2015) also showed that there is a positive relationship between students' performance and interest.

\section{Conclusion}

The results show that the mobile gallery walk (KMGW) method has a positive effect on the students' interest and performance. Meanwhile, there is a significant positive relationship between the student's interest and performance through the mobile gallery walk (KMGW). This finding can help school administrators and teachers where they can focus on encouraging students to use new technology in teaching and learning. Students should be given sufficient knowledge of the steps in using various types of technology. In addition, assistance should be given to students to develop their self-confidence in applying technology in teaching and learning.

\section{References}

Adeyemo, S. A., Adedoja, G. O., \& Adelore, O. (2013). Mobile technology: Implications of its application on learning. International Council for Open Distance Education, 5(3), 249-254.

Chen, D. R., Chen, M. Y., Huang, T. C., \& Hsu, W. P. (2013). Developing a mobile learning system in augmented reality context. International Journal of Distributed Sensor Networks, 9(12), 1-7 
Cohen, J. (1988). Statistical power analysis for the behavioral sciences (2nd ed.). Hillsdale, NJ: Lawrence Earlbaum Associates Publishers, 579.

Darrell, M. W. (2013). Mobile learning: transforming education, engaging students, and improving outcomes. Centre of Technology Innovation, US: Brookings Publiser.

Pedro, D. K. T., Jackson, C., Campbell, E., Gilley, J., \& Clarelli, B. (2016). Creating transinsclusive schools: Introductory activities that enhance the critical consciousness of future educators. International Journal of Teaching dan Learning in Higher Eduction, 28(2), 293-301.

Erma. (2014). Hubungan antara sikap, minat, pengajaran guru dan pengaruh rakan sebaya terhadap prestasi matematik tambahan tingkatan 4. Jurnal kurikulum dan pengajaran asia pasifik, 2(1), 1-10.

Fannia, L., Rini. \& Arman, E. Y. (2017). Penerapan metode pembelajaran gallery walk untuk meningkatkan prestasi belajar peserta didik pada pokok bahasan struktur atom dan sistem periodik unsur du kelas X MIA SMAN2 Pekanbaru. Jurnal Online Mahasiswa: Fakultas Keguruan dan Ilmu Pendidikan, 4(1), 1-13.

Farrah, Z. (2015). Enhancing students' speaking skill through gallery walk technique. English education department, state institute for islamic studies (IAIN) Salatiga, Indonesia. Language and Language Teaching Journal, 8(2), 253-268.

Franzblau, L., \& Haque, F. (2018). Using gallery walks to navigate hospital hierarchy. Medical Education, 52(11), 1185-1186. Blackwell Publishing Ltd

Ghazali, D. H., \& Sufean. (2016). Metodologi penyelidikan dalam pendidikan: Amalan dan analisis kajian. Penerbit Universiti Malaya, Kuala Lumpur.

Halim, A. A. \& Najib, M. H. (2016). Penggunaan aplikasi rangkaian sosial dalam kalangan pelajar Politeknik Kuala Terengganu. Journal of Social Sciences and Humanities, 1(1), 8190.

Hashim, K. F., Tan, F. B., \& Rashid, A. (2014). Adult learners' intention to adopt mobile learning: A motivational perspective. British Journal of Educational Technology, 46(2), 381-390.

Hendri, D., \& Retika, W. A. (2017). The use of gallery walk to enhance the speaking achievement of the ninth grade students of Smp Pgri 1palembang. Jurnal Bahasa Dan Sastra, 6 (1), 50-56.

Kahayun, Wakidi, \& Yustina. (2015). Pengaruh gallery walk terhadap minat belajar sejarah di Sman 1 Natar. Jurnal Pendidikan dan Penelitian Sejarah, 3(2), 1-14.

Kennedy, M. J., Mimmack, J., \& Flannery, K. B. (2012). Innovation in data-driven decision making within SWPBIS systems: Welcome to the gallery walk. Beyond Behavior, 21(3), 814.

Khoo, Y. Y., Al-Huda, A. K., Hafsah, T., Norasibah, A. J., and Radziah, A. (2015). Developing a new method of mobile learning among distance learners in a public university. In: Tang S., Logonnathan L. (eds) Taylor's 7th Teaching and Learning Conference 2014 Proceedings. Springer, Singapore, 215-222.

Kruea-In, N., \& Thongperm, O. (2014). Teaching of science process skills in thai contexts: Status, supports and obstacles. Social and Behavioral Sciences, 141, 1324-1329.

Macaluso, D. K., \& Hughes, A. (2015). The use of mobile apps to enhance student learning in introduction to psychology. Teaching of Psychology, 43(1), 48-52. 
Mariyaningsih, N. (2014). Peningkatan aktivitas dan hasil belajar akuntansi materi laporan keuangan melalui metode gallery walk duati-duata. Jurnal Pendidikan Ekonomi Dinamika Pendidikan, 14(1), 57-59.

Maslin, M., Amirah, S. N., Hasnaa, N., Normeza, W., \& Raihana, M. A. (2016). Mobile learning in Malaysia education institutions. Issues in Information Systems, 17(5), 152-157.

Maulida, Y., Wahab, A., \& Yusuf, H. (2017). Penerapan model pembelajaran kooperatif gallery walk untuk meningkatkan hasil belajar geografi siswa kelas $\mathrm{x}$-b sma negeri 7 takengon. Jurnal Ilmiah Mahasiswa Pendidikan Geografi Unsyiah, 2(2), 59-69.

McCafferty, A., \& Beaudry, J. (2017). The gallery walk: Educators step up to build assessment literacy. Learning Professional, 38(6), 48-53.

Ministry of Education. (2013). Pelan Pembangunan Pendidikan Malaysia 2013-2025. Pendidikan Prasekolah hingga Lepasan Menengah. Putrajaya, Malaysia.

Ministry of Education. (2018). Pengumuman Analisis Keputusan Sijil Peperiksaan Malaysia (SPM) Tahun 2017. Putrajaya, Malaysia

Noorhadi, M., \& Zurinah, T. (2017). Importance of information technology-driven social media in public institutes of higher education. Journal of social sciences and humanities, 14(3), 1-10.

Normala, Shahrun, N., \& Zainizam. (2014). Pengaruh pengetahuan asas ekonomi dan kemahiran matematik terhadap prestasi siswazah UPSI dalam kursus Makroekonomi. Universiti Pendidikan Sultan Idris. e-Proceeding of the World Conference on Integration of Knowledge (WCIK 2014).

Polit, D. F., Beck, C. T., \& Hungler, B. P. (2001). Essentials of nursing research (5th Ed.). Philadelphia: Lippincott Williams \& Wilkins.

Rodenbaugh, D. W. (2015). Maximize a team-based learning gallery walk experience: Herding cats is easier than you think. Advances in Physiology Education, 39(4), 411-413.

Rosnidar, M., Haeidatul, N. H., Norazilawati, A., \& Azmah N. (2015). Keberkesanan penggunaan i-think terhadap pencapaian dan minat murid dalam tajuk sifat bahan, sains tahun 4. Jurnal Pendidikan Sains \& Matematik Malaysia, 5(2). 98-116.

Sabriyadi, Nana, S., \& Tatang, P. (2015). Hubungan antara minat baca dengan prestasi belajar pada mata pelajaran produktif di smk. Journal of Mechanical Engineering Education, 2(1), 124-129.

Shih, J. L., Chuang, C. W., \& Hwang, G. J. (2010). An inquiry-based mobile learning approach to enhancing social science learning effectiveness. Educational Technology \& Society, 13 (4), 50-62.

Simelane, S., \& Mji, A. (2014). Impact of technology-engagement teaching strategy with the aid of clickers on student's learning style. Procedia - Social and Behavioral Sciences, 136, 511-521

Strang, K. D. (2016). Can online student performance be forecasted by learning analytics? International Journal of Technology Enhanced Learning, 8(1), 26-47.

Teodoro, S. D., Donders, S., Davidson, J. K., Robertson, P., \& Schuyler, L. (2011). Asking good questions: Promoting greater understanding of mathematics through purposeful teacher and student questioning, Canadian Journal of Action Research, 12(2), 18-29.

Yang, Y. T. C., \& Wu, W. C. I. (2012). Digital storytelling for enhancing student academic achievement, critical thinking, and learning motivation: A year-long experimental study. Computers \& Education, 59(2), 339-352. 
Zakariya, Y. F., \& Bamidele, E. F. (2015). Investigation into the causes of poor academic performance in mathematics among Nigerian undergraduate students. World Journal of Social Sciences and Humanities, 1(1), 1-5. 